\title{
INSTRUCTIONAL MATERIALS FOR TEACHING PERFORMING ARTS IN WA MUNICIPALITY, GHANA
}

\author{
Samuel Komla Gene and Emmanuel Obed Acquah \\ ${ }^{1}$ Department of Social Science, Nusrat Jahan Ahmadiyya College of Education, Wa \\ ${ }^{2}$ Department of Music Education, University of Education, Winneba
}

Cite this article:

Gene S.K., Acquah E.O.

(2021), Instructional Materials for Teaching Performing Arts in Wa Municipality, Ghana. British Journal of Education, Learning and Development Psychology 4(2), 43-63. DOI: 10.52589/BJELDP-

1XIBV8FD.

\section{Manuscript History}

Received: 3 Oct 2021

Accepted: 23 Oct 2021

Published: 19 Nov 2021

Copyright $\odot 2020$ The Author(s). This is an Open Access article distributed under the terms of Creative Commons AttributionNonCommercial-NoDerivatives 4.0 International (CC BY-NC-ND 4.0 ), which permits anyone to share, use, reproduce and redistribute in any medium, provided the original author and source are credited.
ABSTRACT: The teaching of performing arts at the Basic Schools in Ghana is geared towards the acquisition of skills by learners. Apart from the use of various techniques for teaching the performing arts, the use of the instructional materials is eminent and legitimate for the pupils to have exposure to these materials in order to have first-hand information. However, the selection of instructional materials for teaching and learning of the performing arts, a strand (an aspect) of the creative arts at the Basic Schools has been a daunting task for both new and old teachers, especially, in the Wa Municipality of Ghana. Using the studio-based design, local materials from Wa municipality were collected and new ones were created through the adaptive creative process. It was found out that the preparation of Teaching and Learning materials for creative arts from the local materials is sine qua non to create a hub of teaching resources for instructional deliveries. It is recommended that the headteachers liaise with the appropriate experts to train teachers to use local materials to prepare instructional resources since they are not readily available in the schools for use.

KEYWORDS: Performing Arts, Wa Municipality, Instructional Materials, Creative Arts 


\section{INTRODUCTION}

The implementation stage of every curriculum is crucial and important as it determines the success or failure of the programme. It is at this stage that the teacher considers the methods to employ, types of activities to perform and the instructional materials to use. In recent years the attention of teaching in the abstract has been diverted to the use of activity-based methods of teaching where learners are actively involved during lessons and teachers play the role of a facilitator. To meet the standards and to achieve the set goals, teachers are supposed to use teaching and learning materials and other learning resources during the delivery of lessons. These learning materials could be standardized or improvised instructional materials. In the syllabus of the new Creative Arts subject at the Ghanaian Primary School, the standardized instructional materials for teaching the Performing arts (a sub-strand of the Creative Arts) have been indicated. This includes primary idiophones, secondary idiophones, membranophones and aerophones as indicated in the document developed by the National Council for Curriculum and Assessment (NaCCA, 2019). The performing Arts integrate music, dance and drama and the suggested instrumental resources for teaching these areas are the standardized ones. However, the materials may be improvised if the standardized ones are not there to serve the same purpose. By improvisation, teachers are supposed to gather local materials with the help of pupils to create instructional materials to replace the standardized ones. These instructional materials range from musical instruments, props, costumes and regalia to Information and Communications Technology tools. The two categories of materials are significant for the teaching and learning of the Performing arts to achieve the set goals of education in Ghana.

Again, the teaching of performing arts at the Basic Schools in Ghana is geared towards the acquisition of skills by learners. Apart from the use of various techniques for teaching the performing arts, the use of the instructional materials is eminent and legitimate for the pupils to have exposure to these materials in order to have first-hand information. However, the selection of instructional materials for teaching and learning the performing arts has been a daunting task for both new and old teachers.

In our preliminary study to survey the use of instructional materials for teaching the sub-strand, it became crystal clear that most teachers find it difficult to give better instructions and facilitate the teaching of the performing arts as a result of their inability to improvise recommended instructional materials that are not readily available to be used during instructional hours. It was seen during the preliminary study that the synergy that was to exist between the teachers and learners to improvise the materials was not there. During supervision of Supported Teaching in Schools (STS), an interaction with some headmasters indicated that the teaching of the subject would be made more interesting if teachers would be able to create their own materials for use in the classroom since there was no supply from the government. In the context of this situation, what kind of instructional materials could be created out of the existing local materials to enhance the teaching and learning of the performing arts? In this regard, the study primarily sought to collect local materials available in Wa Municipality of Ghana to create instructional materials for use. The essence was to provide empirical contribution and insight into the creation of instructional materials for teaching performing arts. It is hoped that the outcome would alert the primary school teachers in Wa municipality and across Ghana to some resources available for the construction of improvised teaching and learning materials for teaching the performing arts of the Creative Arts subject in Ghanaian primary schools. 


\section{THEORETICAL FRAMEWORK}

The underpinning philosophy of this work is the Orff method or approach propounded in the 1920s by Carl Orff and his fellow worker Gunild Keetman. According to Shamrock (2019), the theory combines speech with music, movement and play through the process of imitation, leading to exploration and eventually leading to creation. These experiences start with the child at home before they enter school for formal education. Estrella (2019) is also of the view that the method suggests the use of some musical instruments which are termed Orff instruments. These are "xylophones, metallophones, glockenspiels, castanets, bells, maracas, triangles, cymbals, gongs, bongos, steel drums and conga drums are but some of the percussion instruments" (The Orff Approach to Music Education for Children, para.4). Even though the materials for the dance and drama aspects of the performing arts have not been captured in the approach, props and costumes of different forms may be used depending on the topic to be treated. Some of these musical instruments stated in the approach could be found in the majority of Ghanaian communities. Those that could not be found in Ghana, could be replaced with improvised ones. These replacements maybe drums, whistles, xylophones, props and costumes.

In this theoretical framework, the imitation aspect of the Orff approach comes in various ways during the lessons of the performing arts. The teacher may instruct learners to do echo clapping or play a pattern on a drum and ask learners to play the same. Learners may also emulate movements and gestures from either the teacher or peers during lessons. In this regard, Oliver (as cited in McLeod, 2019) concurs that the teacher has to create a serene atmosphere for pupils to become active participants in the learning process and also act as a facilitator rather than an instructor. To achieve this, the teacher has to be conversant with the learners' level of conception in order to direct the learning activities for them to build on the old experience. The effect is that as learners are exposed to various performing arts skills, they try to extend them by investigating similar situations. They deduce meaning from these skills and apply them to other situations and produce their own patterns. They could also create real or improvised materials such as drums, rattles, props and costumes and use them to play to depict real-life situations. As Filianou and Stamatopoulou (2013) posited, "the Orff-Schulwerk and music in special education are discernible in that they make possible the socialization and integration of a child" (p.126). Provisions are made for special needs learners in the mainstream classrooms for them to cope with every lesson that is taught. This is because instructional materials form part of the plans for smooth delivery of lessons and participation of all learners.

\section{REVIEW OF LITERATURE}

\section{The Nature of Performing Arts}

The Performing arts form the basis of every society and play vital roles in the lives of people in diverse ways (Adjepong \& Obeng, 2018). They had been there before the introduction of formal education in Ghana and in the world. According to Adjepong and Obeng (2018), history has it that they are sources of pleasure, entertainment and self-esteem during festive occasions, social activities and the performance of rituals. The performing arts also have economic functions where they are used to advertise goods and services and people engage themselves on them as a source of livelihood. Adjepong and Obeng (2018) reiterated other benefits of the performing arts as follows: 
Students who offer courses in music, dance and drama education in the various universities come out as teachers to teach these arts in various schools across the country. Other graduates practice as sound engineers in recording studios, organists, percussionists, trumpeters and guitarists in various churches. Some of these graduates are composers and conductors who employ their knowledge and skills to form and manage choirs that perform for various religious and social functions for financial reward. (p.223).

Through gestures in dance, dancers greet and praise chiefs and prominent people in the society during festivals and special occasions. In drama, some of the scenes depict sadness and happy moments in life. Lyrics in songs are sometimes used to cast insinuation and to express displeasure at certain occurrences in a community. In assertion to this, Amuah, Adum-Attah and Arthur (2011, p.94), noted that "through singing and dancing, individuals and other members of some communities express their sentiments to portray what they feel about what is going on in society." Elsewhere, music and dance are used to educate people on how to keep their surroundings clean and to observe health practices in order to avoid sickness. In this regard, cultural continuity is imperative in this direction. Teachers need to get the appropriate instructional materials to make lessons as natural as possible.

The history of the performing arts being part of the school curriculum or formal education in Ghana could be traced to the pre-colonial era. Europeans came to the Gold Coast with the intention to trade and to propagate the Gospel and convert the Africans to Christianity. They came from Portugal, Britain, Sweden and Germany. These Europeans built castles and forts where they settled and set up castle schools. The castle schools were meant to educate the children that the European merchants had with the Gold Coast women and to train some Gold Coasters to translate some of the European languages. Some of the African natives were also trained as church catechists. During the colonial era, formal education under Governor Sir Frederick Gordon Guggisberg saw tremendous innovation in his 16 principles of 1920. However, prominence was not given to the performing arts curriculum at the basic school level. It was music that was considered partially. Mereku and Ohene-Okantah (2007) reiterated that music in basic formal education before independence was merely singing of Western hymns and simple anthems. The singing of the Western hymns and simple anthems was done during the morning assembly and school worship time on Wednesdays or Fridays.

After Ghana's independence in 1957, so many educational policies were formulated. Some of these policies were in favour of the inclusion of the performing arts in the school curriculum. The notable ones are the 1985 education act (Curriculum Enrichment Programme) and the 1987 educational reform. The Curriculum Enrichment Programme made provision for the talking drums to be used to summon pupils in the basic schools and students in second cycle institutions. These drums were to replace bells (C.E.P, 1985). The 1987 reform made provision for cultural studies and music to be taught at the Basic Schools. When the 1987 reform was reviewed in 1995, dance was added to the music for the subject to be known as music and dance. Cultural studies were dropped and music and dance were maintained.

In addition to the educational reforms and policies that underpin the inclusion of the performing arts in the school curriculum, Ghana's cultural policy was formulated soon after independence in 1957 and has since then gone through a number of revisions. "The last major update was fashioned at a national stakeholders workshop organized by the National Commission on Culture in 2004" (Kuyini, 2013, p.159). This cultural policy update took place in the year 2004 
during President John Agyekum Kufuor's second tenure of office, as a president of Ghana, under the chairmanship of Professor George Panyin Hagan. The policy was to cater for and streamline cultural activities in Ghanaian societies. The performing arts were supposed to be used to encourage excellence in creativity and the appreciation of Ghanaian dramatic arts and culture. In addition to that, the State would also encourage the formation of associations and groups not only to develop and promote the performing arts but also to seek the welfare of artists. According to National Commission on Culture (2004), the government of Ghana put in place measures to promote the performing arts in Ghana:

The state shall support efforts of the relevant institutions, associations and individuals to undertake research, documentation, development and promotion of traditional and contemporary dance forms. The practice, creation and promotion of all forms of Ghanaian music shall be encouraged by the state. Production of musical instruments shall be encouraged so that all schools and communities can own their own instruments. Drama is not left as the state shall encourage the creation, documentation and extensive production of the dramatic arts through the use of multimedia and information technology. (pp. 31-32).

The role played by some prominent Ghanaians and the performing arts personalities who contributed immensely to the formation of some national and globally recognized performing arts groups cannot be overemphasized. Just after Ghana's independence in 1957, Osagyefo Dr. Kwame Nkrumah founded the National Symphony Orchestra which was established by Dr. Philip Gbeho in 1959. The Abibigromma a theatre group was also established in May 1983 under the leadership of Dr Mohammed Ben Abdallah and two others Mr Asare Newman and Professor William Ofosu Adinku. The group was a resident theatre company of the School of Performing Arts, University of Ghana Legon. It was involved in research works and maintained a global performing arts standard, hence its recognition in Africa and the world (University of Ghana, 2014). Before the formation of the formal and research base performing arts groups after independence in Ghana, there were performing arts groups in almost all Ghanaian communities that were engaged in performance on various occasions for various purposes.

Aside from the policies and the reforms that support the performing arts, there are some organizations and other bodies that contribute to the growth and development of the arts. One of such organizations is the Danish Ghanaian Culture and Development Programme which has made a giant stride in the field of the performing arts by funding and monitoring the activities of some of the artists in Ghana. The entity is a non-profit organization that was formed in 2006. The organization set up a fund known as Ghana Denmark Culture Fund. "The fund provides financial support to cultural events, professional development and artistic creation process as well as exchange projects between Danish and Ghanaian organizations" (Mfum-Mensah, 2011, p.469).

The United Nations Educational, Scientific, and Cultural Organization (UNESCO), plays a vital role in the sustainability and development of the performing arts in various countries and in various ways in the world. Many performing arts groups and organizations have been formed due to the advocacy programmes put in place by UNESCO over the years since its inception. One flagship programme that was set up in the field of the performing arts by UNESCO was the International Theatre Institute (ITI), a subsidiary of UNESCO. The International Theatre Institute, a vibrant institution established the World Performing Arts Capital which was approved by UNESCO in 2013. The goals of the World Performing Arts Capital are to 
"promote education, practice and experience of the Performing Arts by celebrating their diversity and transformative power in a given city, country, or region and potentially even across the world" (Vuong \& Trung, 2021).

The personalities or the pacesetters who in diverse ways and by their frantic efforts the performing arts have been accepted and included in the Ghanaian policy documents and the school curriculum are Professor Joseph Hanson Kwabena Nketia and Professor Albert Mawere Opoku. Just after independence in 1957, Dr. Kwame Nkrumah the first president of Ghana engaged both of them to come out with a contingency plan to encourage and include Ghanaian music and dance in artistic development. This measure saw the formation of the Ghana dance company in 1962. It did not end there. In 1964 both of them designed a curriculum for starting a Certificate in Dance programme at the School of Performing Arts, a division of the Institute of African Studies, University of Ghana, Legon (Green, 2011). All these accounted for the need for the performing arts to be well taught in the schools.

\section{Taxonomies of the Old and the New Performing Arts Curriculum}

The performing arts in Ghana at the Basic Schools are an aspect of the Creative Arts. The Creative Arts consist of visual arts (modelling, drawing, weaving, carving, sewing and casting) and Performing arts (music, dance and drama). Both the old and the new syllabi made provision for the teaching of the three disciplines under the performing arts. These are music, dance and drama. The topics and the themes for teaching these disciplines are selected as such. The old curriculum was objective based where students were to learn and pass examinations at the end of a term or at the end of the programme. It was based on Benjamin Bloom's Taxonomy of 1956. The new curriculum is, however, a standard-based where students are to put whatever they learn to practice or to create new artefacts/compose songs or dance patterns at the end of the term or the programme. It is based on the revised version of Bloom's Taxonomy by Anderson and Krathwohl in 2001. Comparing the new and old taxonomies, the new taxonomy came with changes in terminology and structure. With terminology, the new version replaced the nouns in each level with verbs in the new taxonomy. In assertion to this, Hanna (2007, p. 9) posits that "the authors renamed the knowledge category, for instance, remembering, because knowledge is an outcome of thinking - not a form of thinking". With the structure, Hanna also suggested: "the order of synthesis was swapped with evaluation because creative thinking is a more complex cognitive process than is critical thinking". This can be deduced from figure 2.1 below. 


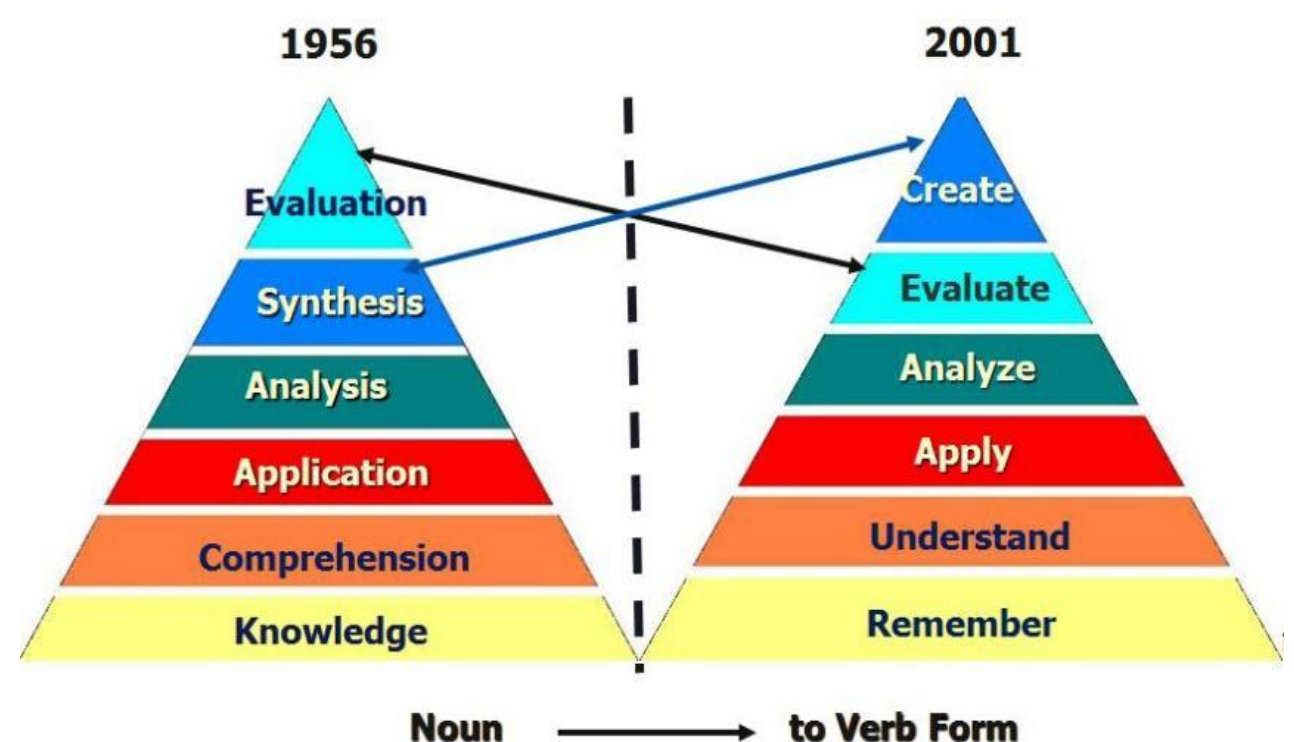

Figure 1: Bloom's Taxonomy Revised by LO, Wilson (2001)

There are so many changes of names for authorities, issues and general overview and framework of the new curriculum as compared with the old one. The following are the differences between the new and the old curriculum at the Primary Schools. The agency that was in charge of the design of the old curriculum was the Curriculum and Research Development Division (CRDD) of the Ministry of Education. With the new curriculum, the National Council for Curriculum and Assessment (NaCCA) an advisory board to the CRDD, was in charge of the design and the education of how to implement the new Primary School curriculum in Ghana. In the new curriculum, the Syllabus is called curriculum. Sections or units as they pertain to the old syllabus are known in the new syllabus as Strands, and topics are sub-strands. Students/pupils in the new curriculum are learners. Scheme of work is the scheme of learning and teachers are facilitators. The Performing arts in the old Creative arts syllabus was outlined in three sections as Performance, Listening and Observing and Composition while the new Creative Arts syllabus has four interrelated sub-strands which are:

- Thinking and exploring ideas

- Planning, making and composing

- Displaying and sharing through exhibition and performance

- Appreciating and appraising

\section{Features of the New Creative Arts Curriculum/Syllabus}

The logic behind the creative arts syllabus/curriculum was that the subject should enable learners to investigate, declare their thoughts and ideas and be determined. These should help them to transfer knowledge and skills to other areas of study. Equally, the creative arts develop the learners' outlook and as such the child is abreast with what is happening around them. The conviction for teaching the subject is that due to technological advancement, it is imperative to 
equip learners with skills in order to cope with the new trends of doing things. Creative arts subject also considers the natural aptitude of every learner in terms of the various aspects of the subject. In this regard, the main focus of the Creative Arts as enshrined in the new curriculum document is:

- equipping learners with creative skills to feature efficiently in the family, community, and the world at large.

- solving problems by examining artistic products and coming out with suitable ideas.

- planning and designing creative self-expression.

- exhibiting and sharing artistic works.

- Valuing and assessing own and other artistic products.

The major roles teachers are supposed to play are to:

- guide pupils to pinpoint the challenges at home, school, and community that bedevil individuals, family and the country.

- lead pupils to probe the consequences of their actions and identify challenges that these actions have on their lives.

- put various measures in place for pupils to come out with the causes and the challenges.

- equip pupils with materials and lead them with activities to develop artistic products.

- direct pupils to design, exhibit and share artworks with classmates and people from the community.

- lead pupils to value, and assess their work and record their results for future reference.

Moreover, the curriculum also contains certain core competencies which learners need to acquire and this is dependent on the expertise that the teachers possess. These competencies are critical thinking and problem-solving, creativity and innovation, communication and collaboration, cultural identity and global citizenship, personal development and leadership, as well as digital literacy (NaCCA, 2019). Learners are to be equipped with skills that will enable them to examine the challenges that bedevil them so that they use the experience from what they learn to overcome the challenges. With creativity and innovation, learners are to use their imagination or original ideas and inventiveness to create new artistic products or improve upon the existing artworks. Communication and collaboration inculcate in learners the expertise of good human relations. This competence helps learners to interact and tolerate each other's views. It is generally known that the world is now a global village and due to advances in technology, Information and Communications Technology (I.C.T) is used as a tool to find, obtain and process information. Cultural identity and global citizenship competence equip learners with socio-economic issues in their community, country and the world. Inculcating all these into the pupils need proper and adequate instructional materials. These materials may be graphical (visual), audio or audio-visual. The graphic materials are two-dimensional in nature and are in the form of banners, pictures, drawings, posts, charts etc. They are the pictorial representation of real objects which teachers use as aids to explain concepts that are difficult 
for pupils to understand. Amadioha (2009) recommended that "when graphic materials are well constructed may help in the processing of information and also aid in the application of principles from other theories" (p. 62). Another type of visual instructional material is still pictures. They consist of the images that are produced from cameras and they are still photographs. They are still in the sense that they cannot move. These materials are also twodimensional in nature. Examples of still pictures are murals, sketches and posters. They are in the following forms: opaque, non-projected and flat. Yet another visual aid is the threedimensional materials. They are the real objects or models or replicas of the visual instructional materials. In teaching and learning the performing arts, the real objects or instructional materials may be different types of musical instruments, costumes, and props. A model is a replica of real objects that have height, width and depth and are considered to be real in teaching and learning situations. In the field of the performing arts, they are known as improvised teaching and learning materials. The three-dimensional materials are objects and specimens, models and mock-ups, diorama and puppets. The still projected pictures are the next type of visual instructional materials. They are produced from filmstrips and overhead projectors. The negative produce images on which light falls to bring out the pictures. Still projected pictures have the quality of accepting a frame of the projected image on a screen at a time. This invariably helps learners to study a particular picture for a long time before another one is projected. The last visual aid to discuss is the motion pictures. A motion picture or movie or film is a series of pictures projected by means of light on a screen in rapid succession. According to Amadioha (2009, p.62), "motion pictures can be projected at 16 or $24 \mathrm{fps}$ (frame per second.) They can be silent or accompanied with sound. Sound films use either a magnetic tape or optical soundtrack for sound recording". Visual instructional materials are used at the introductory stage of a lesson, middle or at the concluding part of a lesson. The following properties of the visual aids must be adhered to, during the preparation of the materials and at the time of the use of the materials. The number of pupils in a class must be considered during the preparation of the materials so that when the material is displayed during lessons, each pupil will be able to see the material clearly. The text and the graphics of the material must be conspicuous and visible. Over decoration of the material must be avoided. Due to their roles in lesson delivery, teachers consider them as significant. These materials make lessons real and at a point in the lesson supplement the teacher's speech. They also serve as a guide to teachers and learners.

Furthermore, audio materials are the equipment and gadgets that produce sounds and aid in the teaching and learning process. These include radios, compact discs and disc players, audio cassettes and cassette players, tape recorders. Wijayanti (2016) commented on the significance of the audio media:

may play distinct roles in the teaching and learning process in the following ways. It may serve as individual tuition for non-readers and visually impaired, stories to encourage the formation of new ideas, and music for fitness and enjoyment (Instructional Technology, para.1). The merits associated with the audio media are that pupils grasp concepts easily during lessons if teachers supplement their discourse with audio materials. The materials could be songs and rhymes which will invariably help in the retention of concepts. (p.32)

Similarly, audio-visual instructional materials also known as multimedia pertain to learning aids that combine the senses of seeing and hearing. These include text, audio, graphics, video and animation. Ashaver and Igyuve as cited in Tang and Intai (2017, p.93) concur that "audio- 
visual aids are materials with both audio and visual presentation to support teaching and learning particularly in improving comprehension and retention". The significant roles of audio-visual materials in teaching and learning cannot be overemphasized as they contribute immensely to the teaching and learning of the performing arts. The instructional materials could be in books, computers or face-to-face discourse. Words could be spoken or printed while the graphics might be still pictures or moving pictures such as film, video clip or animation. Like the cognitive theory of multimedia learning by Mayer (2014), five stages of multimedia learning exist. These are organizing words from the presentation of narratives, choosing pertinent images from the introduced graphics, arranging the chosen words into related verbal rendition, arranging the chosen images into pictures and combining the pictures and words and prior knowledge. The diagram below illustrates the multimedia learning theory.

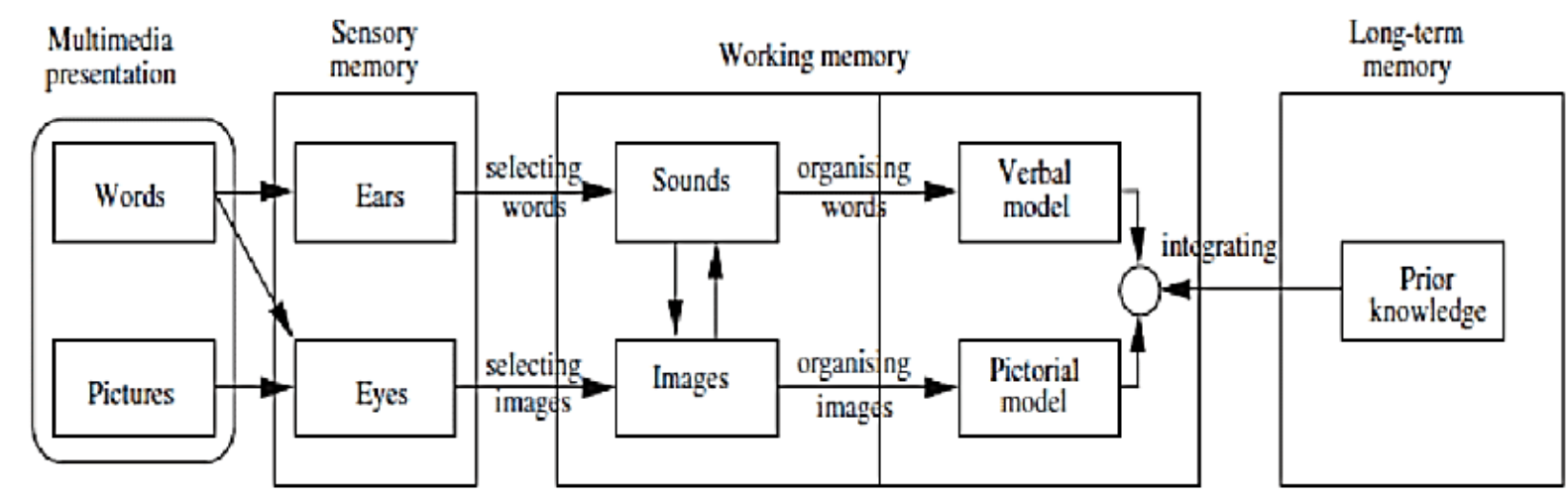

Figure 2: Cognitive Theory of Multimedia Learning (Mayer, 2001)

The diagram shows a copy of multimedia learning which constitutes human learning mechanism. The three memory stores include sensory memory, working memory, and longterm memory. The top row of the boxes represents the audio channel and the bottom row represents the visual channel and the arrows represent the cognitive processes of selecting, organizing, and integrating (Mayer, 2001, p.52).

In summary, the instructional materials help teachers and pupils and make the teaching and learning process efficient. They provide detailed information about topics and guide learners to have adequate information about the subject. The materials also guide learners to learn new things. All the same, the teaching aids are in different forms and they cater for the needs of learners in diverse ways. There are different types of learners like auditory and visual learners. Invariably, these materials aid pupils in different presentations. The availability of instructional materials enables pupils to practice what they learn after class. In an instance where pupils learn how to play a rhythmic pattern, they may practice that on the available instruments after the lesson. 


\section{Categories of Improvised Instructional Materials in Teaching and Learning of the Performing Arts}

It is the wish of every teacher that when lessons are delivered pupils would discern meaning from them and retain the concepts so that they apply these concepts and ideas at the appropriate time. For effective delivery of performing arts lessons, instructional materials play pivotal roles. Right (2018) postulates that "learning materials in teaching are crucial to the success of student achievement" (The importance of learning materials in teaching, para.1). As they are used at the introductory, presentation and closing stages of a lesson. In the absence of standard instructional materials, teachers are compelled to use the available resources in their immediate environment to create improvised teaching aids for the teaching of the subject. Improvisation is the expression and application of creative skills to develop items in place of the real ones. According to Hornby (as cited in Vandeh et al., 2014) "improvisation is a process of constructing objects by using whatever suitable material that is available, usually because you do not have what you really need" (p.195). They further explained that teachers and pupils may decide to improvise dramatic plays and songs either by resorting to the ones already in the system or composing new ones. From the point of view of Ogbu (2016), improvisation is the use of substituted materials and aids to ease teaching and learning in place of the standard materials. To Adu and Adu (2014), improvisation is the act of engaging in the performing arts, speaking, coming out with a masterpiece and reacting to external and inner sentiment. Furthermore, if a teacher produces a surrogate of a particular instructional material, the surrogate for the actual material is termed improvised instructional material. The objective of embracing improvisation in teaching is to inculcate the idea of inventiveness, critical thinking, and manipulative skills in learners. The idea of improvisation also helps teachers to save the cost of production of instructional materials that are called improvised instructional materials. There are numerous definitions of improvised instructional materials. To Himah et al. (2018), they are the replacement for actual learning materials that are effective as the standardized instructional materials. Ahmed (2011) has a similar notion that the instructional media are constructed from materials at hand with the aid of the pundits. Performing arts instructional materials are necessary to both teachers and learners during lessons for demonstration and practice. The improvised instructional materials for teaching the performing arts are classified under three categories. The first category consists of improvised materials that replace the standard materials directly without any alteration of the substituted materials. These are made of some parts of the human body especially the hand for clapping of rhythmic patterns instead of using drums and other instruments. The voice is also used to learn the pattern of drum beats by converting these patterns to "burden text" or "nonsense syllables". Again, the pupils use some of the objects in the classroom as substitutes for actual materials. According to Mereku et al. (2005), during drumming lessons, the teacher should engage the entire class to play patterns on the parts of their body and tables softly. Playing the pattern on the real instruments is to be done outside the classroom in order not to distract the attention of the other classes. As the learner is familiar with the pattern, playing it on a real instrument may not be difficult. The second type of improvised instructional materials for the teaching of the performing arts is the types of local resources that are slightly modified for teaching and learning the subject. These materials include pebbles poured into discarded milo tin and covered to serve as a rattle. Another type of modified local materials for the teaching of the performing arts is the bottle tops attached to old cloth or discarded cloth from tailoring shops to serve as anklets. The third category is the construction of the improvised materials by the use of the available local materials. Different improvised instructional materials are prepared from the following local 
materials: Empty cans (tomato, milk and milo tins), empty cartons, discarded fertilizer and rice bags, different types of ropes, bamboo, sand, pebble, sticks, wood, leaves and others. Improvised instructional materials such as musical instruments, props and costumes are constructed either by the teachers or by experts from the materials stated above. The figure below shows the modes of production of instructional materials.

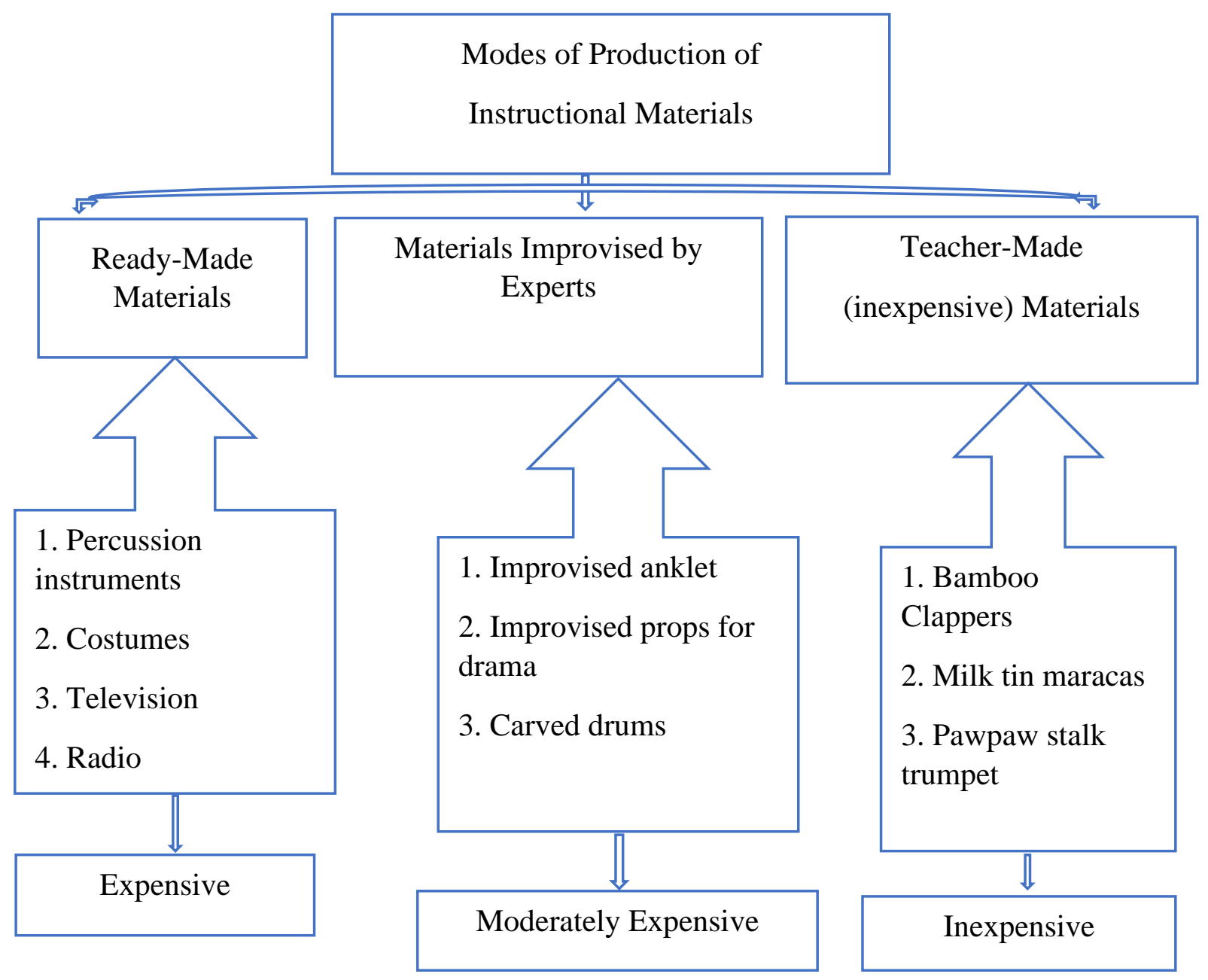

Figure 3: A Diagram Depicting Modes of Production of Instructional Materials

The figure elucidates on the modes of production of improvised instructional materials adapted from Ogunmilade as cited in Olumorin, et al (2010). They are Ready-made materials, materials improvised by experts and teacher-made (inexpensive) materials. The three classes of the materials are graded according to the cost of product acquisition. The ready-made materials consist of textbooks printed by companies, Television sets and projection materials, costumes produced by designers and percussion instruments produced by companies that normally require special materials and several processes for their production. In effect, acquiring these materials is expensive, hence their supply by the government to various schools is at times difficult. The second category of the materials which are improvised by the artisans or experts 
is made up of improvised props for drama, carved drums, improvised anklets to mention a few are considered as moderately expensive materials.

Indeed, some of the materials for improvising these types of learning aids are found in the immediate environment and therefore are not costly as compared with the ones produced by the factories. The third category of learning aids that are considered inexpensive is made from locally sourced materials that need little or no expertise in constructing them. Teachers resort to these types of materials as they could not acquire or afford either the expensive or the inexpensive ones. However, before a teacher could come out with inexpensive improvised materials, he or she has to possess creative skills in or order to be able to construct the materials efficiently.

Acquisition and owning the instructional materials be it standard or improvised is the first step of access to them. The second step is how to handle them with care during and after use for their lifespan to increase. In the course of teaching and learning, the materials that do not have stands could be mounted on tables and those that could be hanged should be handled as such. Pupils should be directed on how to handle the various materials so that they either do not spoil them or the materials damaging them. After the use of the materials, they should be properly stored in such a way that none should be on the ground. They should also be protected such that sunlight and rain may not affect them. In the preparation and acquisition of the instructional materials, the stakeholders of education play significant roles. These stakeholders are the central government, the school authorities, teachers, students/pupils and the chiefs and members of the community.

The government through the policymakers and curriculum developers included the performing arts in the creative arts curriculum. In the syllabus, are the suggested instrumental resources and the other instructional materials. Some of these instructional materials are to be provided by the Metropolitan/ Municipal /District Education Directorate to the basic schools, and the rest to be provided by the Headteacher with either the internally generated fund or the capitation grant. The Headteacher in collaboration with the School Management Committee (S.M.C), the Parent-Teacher Association (P.T.A) sometimes solicits funds and other materials to aid the teachers to acquire the instructional materials. Some of the materials are either not on the market or they are costly so the teacher is compelled to improvise with the available resources sometimes with the help of the pupils. The teachers sometimes borrow costumes, props and musical instruments either standard or improvised from ensemble groups from the community. Some of the members of the community also serve as resource persons. During lessons and basic school cultural festivals, the schools borrow regalia, paraphernalia and musical instruments from the chiefs.

\section{Local Materials for Construction of Instructional Materials}

Local materials are the natural resources that are found at a locality that could be used to create, manufacture or construct artefacts, edifice or teaching and learning materials. Odeyale and Adekunle (2008) suggested that these types of resources are comparatively easy to come by and not costly as the imported ones because they are natural resources and are obtained from the environment. Natural resources are of two types. Renewable and non-renewable resources. Renewable resources are neither preserved before they are used nor depleted when they are being used. However, non-renewable resources cannot be restored or replenished after use. The selected materials for the construction of the instructional materials were based on the renewal 
resources because they are always available, accessible and could be replaced when they wear out. The local materials available at the Wa municipality for the construction of the instructional materials for teaching and learning of the performing arts (music, dance and drama) at the basic schools are gourd, calabash, tin tomato tins, animal skin, pots, sticks, wood and plastic bottles for music. Those that are for the designing of props for the drama aspect are cartons, manila cards, sacks, millet stalk, cotton wool and feathers of birds. The materials for dance are mainly costumes and make-up. The wood ash, charcoal, sacks and fabric were used to prepare the costume and make-up for some selected dances which learners perform during the lessons of the performing arts.

\section{METHODOLOGY}

\section{Design and Sampling}

The study was situated within the studio-based research design. This design is mostly used in Visual Arts to conceptualise it as critical, reflective, investigative praxis (Stewart, 2001). Stewards are of the view that praxis, involves the critical and inextricable meld of theory and practice. This means that the researcher is concerned with processes for theorising practice, using appropriation, pastiche and collaboration as basic tenants. In music research, this design is applicable when the research seeks to develop new knowledge, challenge old beliefs and speculate on the 'what ifs' of our concepts and processes. This new knowledge is made in the context of creating musical artefacts that are relevant to address pertinent issues in the field. As Straka (2019) also postulated, the studio-based design merges the conventions of 'traditional' qualitative methodologies for creative expression.

Within the frame of studio-based, instructional materials that are used for teaching performing arts strands in Wa municipal basic schools were explored while the adaptive design was used to create the instructional materials. Kim and Pierce (2013) noted that "adaptive production technique requires the creation of new forms of products from an already existing one" (p.93). The new material created might look like the original one or take a different shape but might possess the same qualities as the original one and serve the same purpose. The observation was used to collect the existing materials used in teaching three clusters of basic schools selected through the convenience sampling technique. This was followed by the construction of the instruments which were found to be needed by the teachers most, in their instructional deliveries. The constructed instructional materials were gourd drum, double-headed drums with nylon sack and tin tomato cans, cleaves, ankle bells, thumb piano (pempesiwa), milk tin maracas and shakers.

\section{Construction Processes}

Construction of Gourd Drum. The gourd drum was constructed with the following tools and materials: Tools: hack saw, empty beer bottle, knife and needle. Materials: gourd, nylon rope, and goatskin.

Process: cut the gourd with the hacksaw to a required shape. Pour dry sand on the goatskin at where the fur is located and scratch the sand with the tip of the beer bottle to remove the fur from it. Dip the skin into the water for a day to soften it. Remove the skin from the water and engage someone to help you stretch it over the gourd resonator at the opening. Use nylon rope 
to form a ring on top of the opening where the skin covers and beneath the resonator so as to weave the rope through the two rings. Weave through both rings with the rope by piercing the animal skin with the needle to hold the skin firmly onto the resonator.

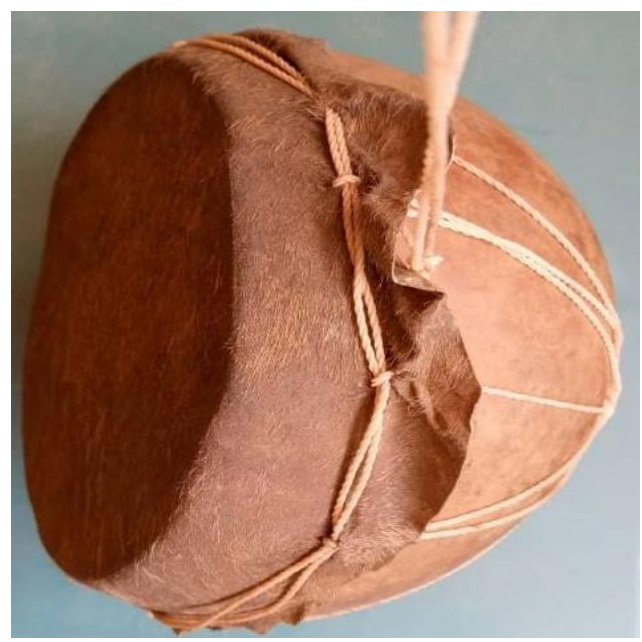

Figure 4: Gourd Drum

\section{Construction of Double-Headed Drums}

Tools: needle, scissors, knife,

Materials: empty tin tomato cans, rope, a nylon sack

Process: open the lids at the two sides of the tomato can. Cut the nylon sack to a required measurement to cover the two openings of the tomato can. Cover both openings of the tomato tin and tie the two ends separately with the rope. Use the needle with the rope to sew the sack at both ends of the tin securely to the opening of the can. Tie the rope and use part of it as a sling to hold or hang during the performance.

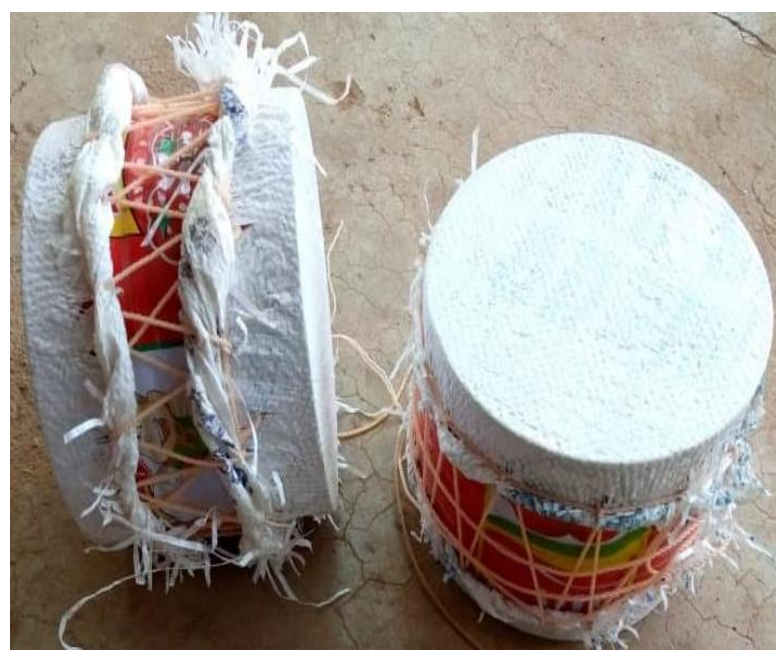

Figure 5: Double-headed Drums made with Tin Tomato Can and Nylon Sack 
British Journal of Education, Learning and Development Psychology

ISSN: 2682-6704

Volume 4, Issue 2, 2021 (pp. 43-63)

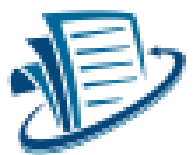

www.abjournals.org

\section{Construction of Cleaves}

Tools: cutlass, knife

Material: sticks

Process: cut the sticks to a required length and remove the bark with a knife. Put it under the sun to dry so as to produce the required sound when the two are struck.

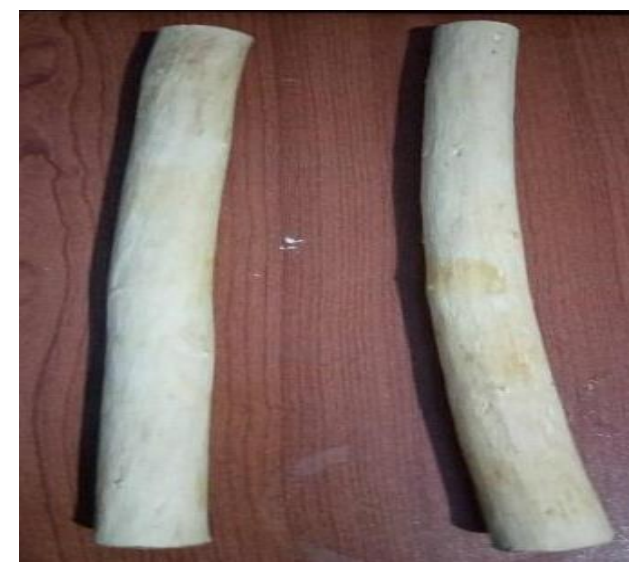

Figure 6: Cleaves

\section{Construction of Ankle Bells onto a Piece of Cloth}

Tools: needle, scissors

Materials: ankle bells, a piece of cloth and rope

Process: cut a piece of cloth to a required length. Sew the ankle bells onto the cloth by passing the rope through the holes of the ankle bells to attach them firmly to the cloth. Attach a rope to two edges in opposite directions to be fastened to the ankle when worn.

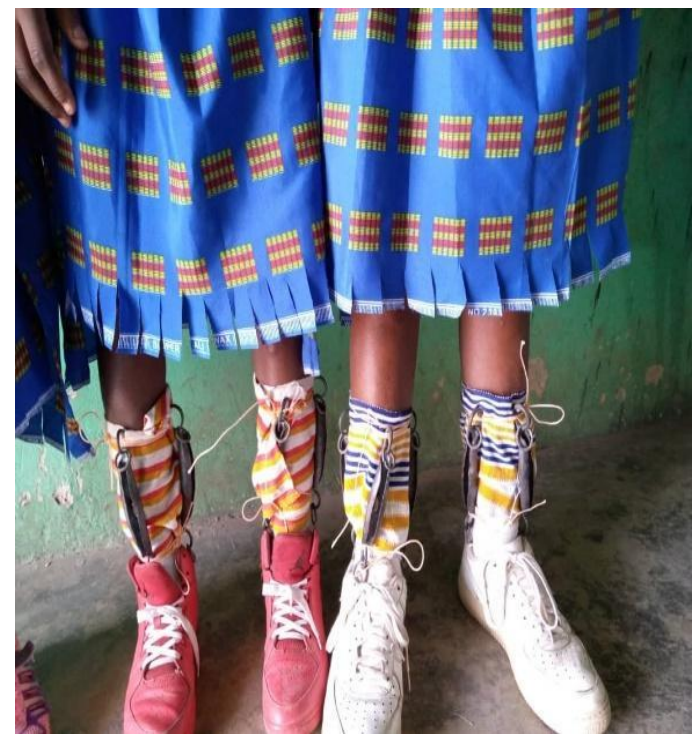

Figure 7: Ankle Bells worn by learners

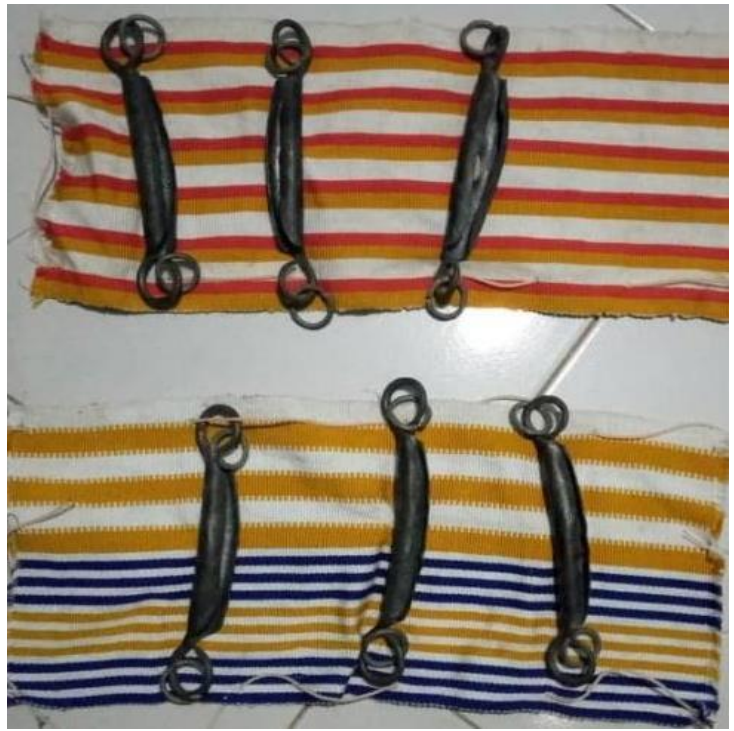

Figure 8: Ankle Bells 


\section{Construction of Thumb Piano/Rhumba Box (Pempesiwa)}

Tools: knife, hammer and saw.

Materials: empty metal gallon, nails, wood, metal strip and a cut out from the gallon and round metal rod.

Process: cut out a portion of the gallon where the wood on which the metal strips to be plucked would be fixed. Engage the services of a carpenter to shape the wood on which the metal strip is to be fixed to a required measurement. Arrange the metal strips on the wood evenly and place the rectangular metal cut out from the gallon at the middle of the metal strips. Nail the metal cut out to the wood with the nails passing between the metal strips. Slot two metal rods between metal strips and the wood nearer to where the strips have been nailed to raise the two ends up for plucking.

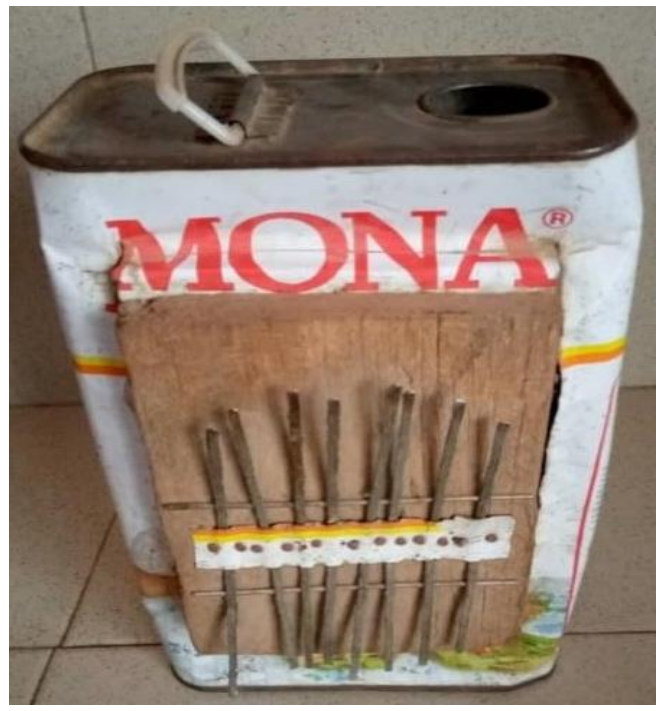

Figure 9: Thumb Piano/ Rhumba box (Pempesiwa)

\section{Construction of Milk Tin Maracas}

Tools: knife, hammer and cutlass

Materials: sticks, nails, milk tins and pebble.

Process: bore a hole at one end of the milk tin where the handle of the maracas could be pushed through. Cut the stick which is going to serve as a handle to the required measurement and remove the buck from it. Put 20 pieces of pebbles into the milk tin through the hole. Push the handle through the hole to touch the other end of the milk tin. Nail the handle to the milk tin to make it firm. 


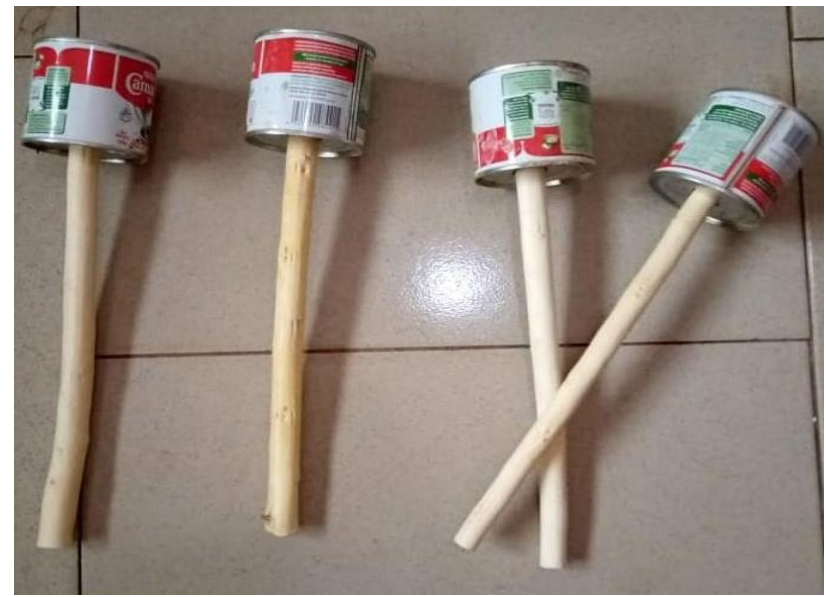

Figure 10: Milk Tin Maracas

\section{Construction of Shakers}

Tools: plier, scissors, hammer, can opener and nail. Materials: lid of tomato tin, wire, nails

Process: open the tin tomato can. Use a nail and hammer to bore holes at the edges of the lid. Nail a metal handle to the lid. Cut the wire with the plier to the required measurement and fit them into the holes. Use the plier to bend the cut wires in the holes to form a ring so as not to fall from the holes.

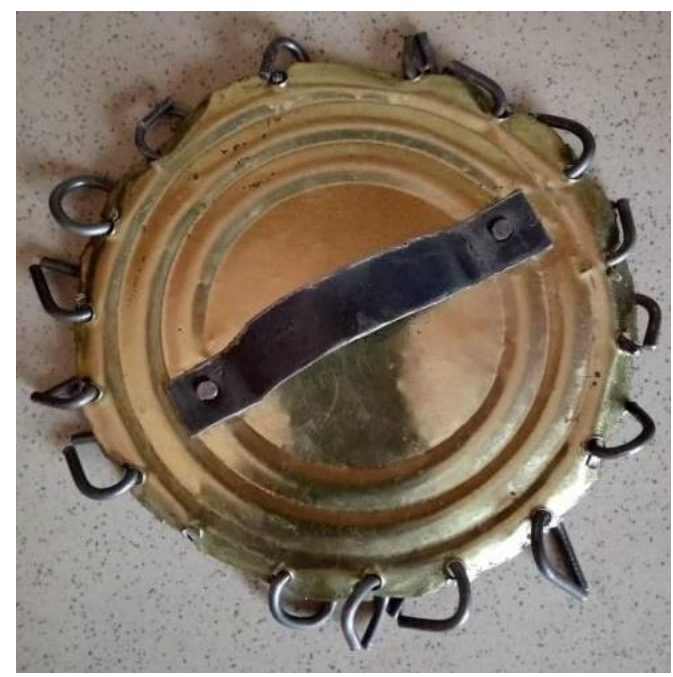

Figure 11: Shakers 


\section{CONCLUSIONS AND RECOMMENDATIONS}

In addition, the construction of some of the learning aids demanded special skills to be able to construct. Two such materials were the gourd drum and the rhumba box. In the case of the rhumba box/thumb piano, fixing the metal strips attached to the wooden board to produce the required sound demanded special attention for it to produce the desired sound. The local materials for the construction of the instructional materials for teaching the performing arts are diverse and numerous. The materials could be found in their natural states or in waste form. They are in three forms namely ready-made materials, those improvised by experts and teachermade materials. Teachers could improvise some of them with the use of local materials which they could instruct learners to collect or headteachers providing them which they also failed to do. Few interactions with the teachers indicated that some of the topics in the curriculum would be very difficult to teach if teaching and learning resources are not provided. It is therefore recommended that the headteachers liaise with some of the stakeholders of education to acquire costumes, props and musical instruments for the school permanently for demonstration during performing arts lessons so that learners may have first-hand information. The teachers should contact the headteachers to aid in the acquisition of some materials and also engage learners in the collection of the local resources that are related and convenient for the preparation of some of the instructional materials. In addition, teachers should be encouraged to liaise with the communities in which they work so as to engage the services of the artisans in the preparation of the instructional materials and to engage some of the artisans as resource persons.

\section{REFERENCES}

Adjepong, B. \& Obeng, P. (2018). The role of performing arts in Ghanaian society and its implication for formal education in Primary Schools. European Journal of Education Studies, 5(6), 22-227.

Adu, F.O.\& Adu, E.I. (2014). Improvisation as a tool for improving the teachers' knowledge in basic technology. IOSR Journal of Research \& Method in Education (IOSR-JRME), 4(1) 14-18.

Ahmed, A. M. (2011). Improvisation of instructional materials for the teaching of biology, an important innovation in the Nigerian educational system. Pristine Journal, 50, 1-7.

Amadioha, W.S. (2009). The importance of instructional materials in our schools, an overview. New Era Research Journal of Human, Educational and Sustainable Development, 2(4), 61-63.

Amuah, I.R., Adum-Attah, K. \& Arthur K. (2011). Music and Dance for Colleges of Education: Principles and Practice. Kramad Publication Ltd.

Curriculum Enrichment Programme, (1985). Curriculum enrichment programme. Ghana Education Service.

Estrella, E. (2019). The Orff Approach to Music Education for Children. Retrieved October 12, 2019, from https://www.liveabout.com/the-orff-approach-2456422

Filianou, M. \& Stamatopoulou, A. (2013). Orff-Schulwerk in special education: A case study. Approaches: Music Therapy \& Special Music Education, Special Issue, 5(2), 125-131.

Gee, J. (January 20, 2012). Importance of prior knowledge to learning. Retrieved from https://news.illinoisstate.edu/2012/01/importance-of-prior-knowledge-to-learning/

Green, D. (2011). The saga of African dance and black studies departments. The Journal of Pan African Studies. 4(6), 16-30. 
British Journal of Education, Learning and Development Psychology

ISSN: 2682-6704

Volume 4, Issue 2, 2021 (pp. 43-63)

www.abjournals.org

Himah, V.O., Parker, J. \& Asare, I. (2018). Improvised materials on the study of science in basic schools in Aowin Municipality-Ghana. Research on Humanities and Social Studies, 8(8), 20-23.

Janovsky, A. (2015). Instructional Materials: Definition, Examples \&Evaluation. Retrieved from https://study.com/academy/lesson/instructionalmaterials.

Kim, K.H., Pierce R.A. (2013). Adaptive Creativity and Innovative Creativity. In: Carayannis E.G. (eds) Encyclopedia of Creativity, Invention, Innovation and Entrepreneurship. Springer, New York, NY. https://doi.org/10.1007/978-1-4614-3858-8_21

Kuyini, A. B. (2013). Ghana's education reform 2007: A realistic proposition or a crisis of vision?. International Review of Education, 59(2), 157-176.

LO, W. (2001). Anderson and Krathwohl-Understanding the New Version of Bloom's Taxonomy: A Succinct Discussion of the Revisions to Bloom's Classic Cognitive Taxonomy by Anderson and Krathwohl and how to use them effectively. The Second Principle: The work of Leslie Owen Wilson (Doctoral dissertation).

Mayer, R.E. (2001). Multimedia learning. Cambridge University Press.

Mayer, R.E. (2014). Cognitive theory of multimedia learning. Cambridge University Press

McLeod, S. A. (2019). Zone of proximal development. Retrieved from www.simplypsychology.org/Zone-of-Proximal-Development.html

Mereku, C.W.K \& Ohene-Okantah, M. (2007). Music and dance for the basic school teacher. IEDE.

Mereku, C.W.K., Addo, G.W., \& Ohene-Okantah, M. (2005). Teaching music and dance in the Junior Secondary Schools. Adwinsa Publications

Mfum-Mensah, O. (2011). Education collaboration to promote school participation in northern Ghana: A case study of a complementary education program. International Journal of Educational Development, 31(5), 465-471.

NaCCA. (2019). Creative arts curriculum for Primary Schools (Basic 4-6). Retrieved March 4, 2020, from www.nacca.gov.gh

National Commission on Culture. (2004). Cultural Policy of Ghana. Accra, NCC.

Odeyale, T. O., \& Adekunle, T. O. (2008). Innovative and sustainable local material in traditional African architecture: Socio-cultural dimension. In D. D'yala \& E. Fodde (Eds.), Structural analysis of historical construction: Preserving safety and significance (pp. 991-998). Taylor \& Francis.

Olumorin, C. O., Yusuf, A., Ajidagba, U. A. \& Jekayinfa, A. A. (2010). Development of instructional materials from local resources for art-based courses. Asian Journal of Information Technology, 9, 107-110.

Right, J. (June 27, 2018). The Importance of Learning Materials in Teaching. Retrieved from https://www.theclassroom.com/importance-learning-materials-teaching-

Shamrock, M. (2019). The Orff-Schulwerk Approach. Retrieved from https://www.allianceamm.org/resources/orff-schulwerk/

Stewart, R. (2001). Practice v praxis: Constructing models for practitioner-based research. Paper presented at the ACUADS Conference, Adelaide.

Straka, A. (2019), Structuring arts-based analysis in portraiture research, Qualitative Research Journal, 20(1), DOI 10.1108/QRJ-05-2019-0045.

Tang D. K. H., \& Intai, R. (2017). Effectiveness of audio-visual aids in teaching lower secondary science in a rural secondary school. Asia Pacific Journal of Educators and Education, 32, 91-106. Retrieved from https://doi.org/10.21315/apjee2017.32.7

University of Ghana (2014). Abibigromma Theatre Company. Retrieved from https://spa.ug.edu.gh/abibigromma/overview 
British Journal of Education, Learning and Development Psychology

ISSN: 2682-6704

Volume 4, Issue 2, 2021 (pp. 43-63)

www.abjournals.org

Vandeh, C.M., Gbaa, D.J. \& Awambe, K.E. (2014). Improvisation of instructional materials in an inclusive environment in Nigeria. National Journal of Inclusive Education, 2(1), 194-201.

Vuong, Q. H., \& Trung, T. (Eds.). (2021). Academic Contributions to the UNESCO 2019 Forum on Education for Sustainable Development and Global Citizenship. MDPI.

Wijayanti, R. (2016). Instructional technology. Retrieved from http://pascapbi3a.blogspot.com/2016/12/audio-media.html 